\title{
ANALISIS BEBAN KERJA TENAGA PENDIDIK DAN KEPENDIDIKAN DI FAKULTAS Y UNIVERSITAS X
}

\author{
Nindi Aristi, Hanny Hafiar \\ Fakultas Ilmu Komunikasi, Universitas Padjadjaran
}

\begin{abstract}
ABSTRAK
Peneliti melakukan penelitian tentang analisis beban kerja tenaga kependidikan di Fakultas Y Universitas X. Fokus penelitiannya adalah beban kerja berdasarkan analisis pekerjaan dan beban kerja berdasarkan kinerja pegawai. Penelitian yang menggunakan metode deskriptif kuantitatif (generic quantitative inquiry) yang memberikan gambaran atas beban kerja yang diemban oleh tenaga kependidikan di Fakultas Y Universitas $X$. Sampel penelitian mengambil keseluruhan jumlah tenaga kependidikan dengan teknik pengumpulan data melalui penyebaran kuesioner tertutup. Hasil penelitian menunjukkan bahwa tenaga kependidikan di Fakultas $\mathrm{Y}$ Universitas $\mathrm{X}$ telah melakukan tugas dan tanggung jawab yang sesuai dengan beban kerjanya.
\end{abstract}

Kata-kata kunci: Analisis beban kerja, tenaga pendidik, tenaga kependidikan

\section{WORKLOAD ANALYSIS OF EDUCATION AND EDUCATIONAL PERSONNEL IN FACULTY Y UNIVERSITY X}

\begin{abstract}
Researchers conduct a study on the workload analysis of educational personnel in the Faculty of $Y$ at the University of $X$. The focus of this research is based on workload analysis and job workload based on employee performance. Thy study uses quantitative descriptive method (generic quantitative inquiry) that provides an overview of the workload performed by academic staff in the Faculty of $Y$ at the University of $X$. Sample of this research is taken from educational personnel data collection techniques through questionnaires. The results show that the academic staff in the Faculty of $Y$ at $X$ University has undertaken the task and responsibilities based on the workload being given.
\end{abstract}

Key words: Analysis of workload, educator, education personnel

Korespondensi: Nindi Aristi, S.Sos., M.Comn. Fakultas Ilmu Komunikasi Universitas Padjadjaran, Jl. Raya Bandung-Sumedang KM. 21 Sumedang.Email: n_aristi@yahoo.com 


\section{PENDAHULUAN}

Dalam rangka mendukung kelancaran penyelenggaraan tugas tenaga pendidik dan kependidikan di sebuah fakultas, maka diperlukan jumlah dan mutu sumber daya manusia yang tepat untuk mampu memberikan pelayanan bagi semua stakeholder secara optimal. Kualitas layanan sebagai fungsi pendukung di perguruan tinggi menuntut pengelolaan sumber daya manusia yang mendorong kinerja karyawan dalam penghantaran layanan secara profesional.

Fakultas Y Universitas X sebagai badan hukum milik negara yang bersifat nirlaba, mendayagunakan seluruh keuntungan yang diperoleh dari usaha bisnisnya untuk kepentingan peningkatan kualitas pendidikan. Penyelenggaraan pendidikan di Fakultas Y Universitas X dalam rangka pencapaian tujuannya menghasilkan lulusan yang berkualitas juga tidak terlepas dari peran serta tenaga pendidik dan tenaga kependidikan sebagai sumber daya penunjang.

Upaya Fakultas Y Universitas X dalam rangka mencapai tujuan menghasilkan lulusan yang berkualitas untuk menghadapi tuntutan pembangunan dapat dilakukan melalui suatu pengelolaan organisasi yang efektif dan efisien. Pengelolaan organisasi yang efektif dan efisien dapat dilakukan di seluruh bidang termasuk bidang pengembangan sumber daya manusia (SDM). SDM organisasi di lingkup Fakultas Y Universitas $\mathrm{X}$ (dalam hal ini karyawan) merupakan salah satu aset perusahaan yang juga harus dikelola dengan baik.

Usaha yang efektif dan efisien mengandung arti bahwa output yang dihasilkan oleh setiap karyawan memenuhi apa yang ditargetkan oleh organisasi. Berdasarkan jumlah output atau hasil kerja yang mampu dihasilkan oleh setiap karyawan, dapat diketahui berapa jumlah karyawan yang sesungguhnya diperlukan oleh perusahaan untuk mencapai target. Hal tersebut dapat dilakukan melalui suatu pengukuran beban kerja, sehingga karyawan dapat bekerja optimal sesuai kemampuannya.

Beban kerja seseorang sudah ditentukan dalam bentuk standar kerja perusahaan menurut jenis pekerjaannya (Mangkuprawira, 2003). Beban kerja yang dibebankan kepada karyawan dapat terjadi dalam tiga kondisi. Pertama, beban kerja sesuai standar. Kedua, beban kerja yang terlalu tinggi (over capacity). Ketiga, be- ban kerja yang terlalu rendah (under capacity). Beban kerja yang terlalu berat atau ringan akan berdampak terjadinya inefisiensi kerja. Beban kerja yang terlalu ringan berarti terjadi kelebihan tenaga kerja. Kelebihan ini menyebabkan organisasi harus menggaji jumlah karyawan lebih banyak dengan produktifitas yang sama sehingga terjadi inefisiensi biaya. Sebaliknya, jika terjadi kekurangan tenaga kerja atau banyaknya pekerjaan dengan jumlah karyawan yang dipekerjakan sedikit, dapat menyebabkan keletihan fisik maupun psikologis bagi karyawan. Akhirnya karyawan pun menjadi tidak produktif karena terlalu lelah.

Untuk itu diperlukan program pengelolaan sumber daya manusia yang mampu memfasilitasi kinerja sumber daya manusia sehingga kinerja pelayanan dapat dioptimalkan. Dalam pengelolaan sumber daya manusia, analisis beban kerja berperan sebagai informasi dasar bagi program pengelolaan sumber daya manusia yang lain.

Analisis beban kerja merupakan kajian terhadap seberapa besar volume pekerjaan yang dibebankan pada suatu unit organisasi dan karyawan dalam yang menjamin ketercapaian rencana strategis di masa yang akan datang. Analisis beban kerja akan memberikan informasi tentang kualitas dan kuantitas sumber daya manusia yang diperlukan disetiap unit sehingga dapat dilakukan identifikasi kelebihan atau kekurangan pegawai.

Berdasarkan analisis beban kerja sumber daya manusia, maka, organisasi dapat merencanakan program staffing, pelatihan, pembinaan, dan pengembangan pegawai sehingga kinerja SDM dapat sejalan dengan kinerja unit dan organisasi. Dalam Peraturan Kepala Badan Kepegawaian Negara, yang dimaksud dengan beban kerja adalah sejumlah target pekerjaan atau target hasil yang harus dicapai dalam satu satuan waktu tertentu (BKN, 2011). Lebih lanjut analisis beban kerja adalah suatu teknik untuk menetapkan jumlah pegawai yang dibutuhkan dan waktu yang digunakan dalam menyelesaikan suatu pekerjaan untuk mencapai tujuan organisasi.

Dalam kajian manajemen sumber daya manusia, analisis beban kerja merupakan langkah logis berikutnya setelah analisis tugas dan fungsi. Analisis tugas dan fungsi mengumpulkan daftar tugas utama. Sedangkan analisis beban 
kerja mengungkit daftar tugas utama untuk memahami beberapa hal yakni (a) Apa yang dikerjakan pegawai? (b) Kapan mereka melakukan pekerjaan tersebut? (c) Keterampilan apa yang dibutuhkan oleh pegawai?, dan (d) Hubungan atau interaksi kritis atau penting antara pegawai dan sistem?

Fakultas Y Universitas X yang merupakan lembaga pendidikan tinggi negeri memiliki tugas mulia untuk mencerdaskan bangsa. Demi mendukung tugas mulia tersebut, efisiensi dan efektifitas organisasi mutlak harus diwujudkan dan dipelihara. Hal ini dikarenakan ketidakefisienan akan menyebabkan turunnya produktivitas organisasi dan mengancam pelaksanaan pencapaian tujuan mulia Fakultas Y Universitas $X$. Hal inilah yang kemudian melatarbelakangi pentingnya melakukan analisis beban kerja di lingkungan kerja Fakultas Y Universitas X.

Saat ini terdapat pergeseran cara pandang terhadap sumber daya manusia perusahaan. Sumber daya manusia tidak lagi dipandang hanya sebagai karyawan tetapi juga sebagai rekan atau partner perusahaan, sehingga sumber daya manusia harus diperlakukan dan dikelola dengan baik. Perencanaan tenaga kerja yang baik adalah hal yang penting untuk dilakukan yaitu meliputi analisis pekerjaan dan beban kerja perusahaan secara keseluruhan.

Menurut Moekijat (2008), analisis beban kerja merupakan metode yang biasa digunakan untuk menentukan jumlah atau kuantitas tenaga kerja yang diperlukan. Beban kerja yang didistribusikan secara tidak merata dapat mengakibatkan ketidaknyamanan suasana kerja karena karyawan merasa beban kerja yang dilakukannya terlalu berlebihan atau bahkan kekurangan.

Berdasarkan uraian diatas dapat dirumuskan beberapa permasalahan yang hendak dikaji, yaitu bagaimana gambaran beban kerja tenaga kependidikan Fakultas Y Universitas $\mathrm{X}$ berdasarkan faktor analisis pekerjaan? dan bagaimana kinerja tenaga kependidikan Fakultas Y Universitas X berdasarkan faktor kinerja kerja?

\section{METODE PENELITIAN}

Metode kajian yang digunakan adalah metode penelitian deskriptif. Metode ini digunakan untuk memaparkan gambaran mengenai penggunaan jam kerja serta beban kerja tenaga pendi- dik dan kependidikan Fakultas Y Universitas $\mathrm{X}$ hingga dapat dijadikan dasar bagi pimpinan dan pengelola sumber daya manusia Fakultas Y Universitas $X$ untuk membuat kebijakan yang sesuai dengan kemampuan sumber daya manusia internal Fakultas Y Universitas X.

Metode ini bertujuan untuk memaparkan data-data, yang kemudian dilakukan analisis terhadap data-data yang terkumpul dan tersusun tersebut. Terdapat dua sumber data yang digunakan dalam kajian ini yakni, data primer dan data sekunder. Kedua data tersebut bersifat kuantitatif dan kualitatif yang selanjutnya menjadi landasan peneliti untuk menganalisisnya.

\section{HASIL DAN PEMBAHASAN}

Terdapat sembilan belas pembahasan yang didapatkan dari penelitian ini. Pertama mengenai pengetahuan mengenai adanya pedoman dan petunjuk kerja. Hasil penelitian ini menunjukkan bahwa sebagian besar $(59,375 \%)$ tenaga kependidikan mengetahui adanya pedoman atau petunjuk kerja. Adapun uraian tugas pokok tenaga kependidikan di Fakultas Y Universitas $\mathrm{X}$ meliputi unsur-unsur tugas pelayanan akademik dan kemahasiswaan yang terdiri dari (1) Membuat surat-surat yang berhubungan dengan akademik dan kemahasiswaan, (2) Pendistribusian transkrip nilai, (3) Legalisasi ijazah, (4) Membuat rekapitulasi IPK mahasiswa, (5) Input data akademik mahasiswa, (6) Pengaturan jadwal kuliah mahasiswa, (7) Pengaturan jadwal kegiatan kemahasiswaan, dan (8) Pengaturan jadwal kegiatan fakultas.

Pengetahuan pedoman atau petunjuk kerja merupakan hal yang penting untuk diketahui oleh setiap pekerja. Hal ini disebabkan, setiap pekerjaan harus dikerjakan sesuai dengan pedoman yang mengatur tentang standar kinerja sehingga dapat dinilai secara aktual dan terukur.

Terdapat beberapa syarat mengenai standar kinerja, antara lain standar kinerja haruslah mudah diukur, standar kinerja haruslah dipahami oleh karyawan dan penyelia, dan standar kinerja haruslah memberikan penafsiran yang tidak mendua (Simamora, 1987: 149)

Mengacu pada penyataan tersebut, maka pengetahuan karyawan mengenai pedoman kerja merupakan faktor penting dalam terlaksanakannya pekerjaan dengan baik. Kurangnya pengetahuan karyawan terhadap poin-poin 
penting dalam pedoman kerja dapat menyebabkan pekerjaan tidak dapat dilaksanakan dengan baik sesuai dengan ketetapan yang telah tercantum dalam pedoman sehingga meningkatkan resiko kesalahan pengerjaan dalam melakukan pekerjaan tertentu.

Kedua, mengenai kejelasan pedoman kerja. Dari hasil penelitian ini dapat dilihat bahwa sebagian besar $(56,25 \%)$ tenaga kependidikan memahami pedoman kerja secara jelas. Pedoman kerja digunakan untuk membantu para tenaga kependidikan menjalankan tugas pokok dan fungsinya masing-masing.

Setiap struktur organisasi yang formal, harus memiliki peraturan. Hal ini merujuk pada pernyataan bahwa: struktur organisasi yang dipandang formal adalah struktur dimana peraturan dan prosedur merupakan pedoman atas hal-hal yang harus dilakukan individu dalam perusahaan (Gibson, Ivancevich dan Donnely, 1996: 27). Berdasarkan jawaban responden diketahui bahwa pedoman kerja telah cukup dipahami oleh sebagian besar pekerja.

Banyak organisasi yang telah memiliki pedoman kerja dan pedoman tersebut telah dibagikan bahkan diletakan di tempat-tempat strategis untuk memudahkan para pekerja untuk membacanya. Namun sesungguhnya pedoman kerja tidak cukup jika hanya dibaca dan diketahui, karena hal yang penting adalah pedoman tersebut dipahami secara benar dan diinterpretasi dengan makna yang sama oleh setiap pekerja, sehingga tidak menimbulkan perbedaan pendapat yang mengarah pada kesalahan pengerjaan pekerjaan yang disebabkan oleh pemahaman dari tiap-tiap karyawan yang berbeda terhadap pedoman tersebut.

Ketiga, mengenai kejelasan tugas dan tanggung jawab pekerjaan yang harus dilakukan tenaga kependidikan. Sebagian besar $(53,125$ $\%$ ) tenaga kependidikan memahami tugas dan tanggung jawab yang harus dilakukan dengan jelas. Setiap pekerja memiliki tugas dan tanggung jawab masing-masing berkaitan dengan jenis pekerjaan yang dikerjakannya. Setiap pekerjaan sebaiknya dikondisikan berada dalam koridor formal. Artinya dilakukan formalisasi tugas dan tanggung jawab, sehingga tugas-tugas pekerjaan ditentukan oleh hukum-hukum, aturan-aturan, apakah dinyatakan langsung atau dimengerti begitu saja oleh pegawai. Persepsi para pegawai mengenai derajat spesifikasi da- lam pelaksanaan prosedur dan kegiatan kerja memberikan suatu ukuran yang jelas dalam suatu organisasi (Mulyana, 2002: 152).

Pemahaman tiap karyawan terhadap tugas dan tanggung jawabnya masing-masing merupakan hal penting yang harus didahulukan. Hal ini disebabkan sikap mental dan sikap kerja tiap karyawan berbeda-beda. Perbedaan sikap mental dan sikap kerja ini biasanya berdampak pada bertumpuknya pekerjaan pada sorang pekerja tertentu yang cenderung tidak asertif. Hal ini dapat menimbulkan kekacauan manajemen dalam melakukan fungsinya.

Oleh karena itu berdasarkan data penelitian mengenai pemahaman karyawan terhadap tugas dan tanggung jawab pekerjaannya masingmasing yang menunjukkan angka yang cukup baik maka dapat diharapkan bahwa setiap tugas yang dibebankan kepada setiap pekerja dapat dilaksanakan dengan baik.

Empat, mengenai kesesuaian pedoman kerja yang dibuat dengan pengetahuan, kemampuan dan keahlian yang dimiliki oleh tenaga kependidikan. Sebagian besar $(59,375 \%)$ tenaga kependidikan memperoleh bimbingan yang diberikan atasan saat melaksanakan tugas. Setiap karyawan diharapkan mampu melaksanakan tugas dan tanggungjawab pekerjaan yang dibebankan kepada masing-masing pekerja. Untuk itu setiap karyawan harus memiliki pengetahuan, kemampuan dan keahlian untuk menyelesaikan tugas-tugasnya sesuai dengan pedoman kerja. Hal ini mengacu pada pernyataan bahwa, seorang pekerja harus memiliki kualifikasi; (a) Memahami tujuan, tugas pokok dan fungsi organisasi, (b) Menguasai landasan prinsip yang dianut organisasi, (c) Memahami sistem pembagian tugas dalam organisasi, dan (d) Menerima dan memahami posisi kerja sebagai bagian dari proses manajemen (Sedarmayanti, 2001: 306).

Setiap pekerja telah melalui proses rekrutmen berupa ujian seleksi baik yang berbentuk tertulis maupun wawancara. Pengetahuan, kemampuan dan keahlian tiap pekerja sesungguhnya telah teridentifikasi sejak awal proses seleksi, sehingga mereka yang diterima sebagai pekerja dapat dianggap sebagai individu-individu yang memiliki pengetahuan, kemampuan dan keahlian yang sesuai dengan kebutuhan organisasi akan sumber daya manusia.

Selanjutnya, pengetahuan, kemampuan dan keahlian tiap karyawan tinggal disesuaikan 
dengan spesifikasi pekerjaan yang ada dalam organisasi yang tertuang dalam pedoman kerja, sehingga setiap pekerjaan dapat dilaksanakan dengan baik oleh setiap karyawan sesuai dengan standar kinerja dan prosedur pengerjaan yang telah ditetapkan

Lima, mengenai adanya atasan yang memberikan bimbingan dalam melaksanakan tugas. Sebagian besar $(59,375 \%)$ tenaga kependidikan memperoleh bimbingan yang diberikan atasan saat melaksanakan tugas. Dalam suatu organisasi, sering terjadi adanya suatu pekerjaan yang sama tetapi harus dilakukan secara berulang. Pekerjaan tersebut biasanya diinstruksikan oleh pimpinan kepada pekerja tertentu. Suatu pekerjaan yang diinstruksikan oleh pimpinan dapat dituangkan dalam bentuk petunjuk. Petunjuk merupakan pernyataan kehendak pimpinan atas suatu pekerjaan tertentu (Sedarmayanti, 2001: 294).

Petunjuk pelaksanaan pekerjaan sebaiknya tetap berada dalam pengawasan dan bimbingan pimpinan. Dengan adanya data mengenai sebagian besar tenaga kependidikan memperoleh bimbingan yang diberikan atasan saat melaksanakan tugas, menunjukkan bahwa pimpinan tersebut telah melaksanakan fungsi dan tanggungjawabnya dengan baik.

Berdasarkan data penelitian dapat diketahui bahwa pimpinan telah melaksanakan tugasnya dalam membimbing karyawan dalam mengerjakan pekerjaan tertentu, sehingga responden cenderung menilai bahwa pimpinan telah melakukan pembimbingan pada karyawan saat melaksanakan tugas-tugas yang menjadi pekerjaannya.

Hal ini patut dipertahankan dan ditingkatkan, mengingat dalam tugas-tugas rutin, seringkali pimpinan beranggapan bahwa seharusnya pekerja sudah memahami dan mampu melaksanakan pekerjaan tanpa perlu bimbingan dari atasan.

Enam, mengenai kesesuaian tugas dan tanggung jawab yang diberikan dengan kemampuan dan keahlian tenaga kependidikan. Sebagian besar $(56,25 \%)$ tenaga kependidikan memiliki kemampuan dan keahlian sesuai dengan tugas dan tanggung jawab yang diberikan. Setiap pekerjaan membutuhkan kemampuan dan keahlian yang spesifik. Spesifikasi pekerjaan pada akhirnya menghasilkan spesialisasi kemampuan. Hal ini disebabkan adanya kecenderun- gan suatu pekerjaan tertentu diserahkan kepada individu tertentu, dengan demikian individu tersebut pada akhirnya akan semakin terasah kemampuan dan keahliannya untuk mengerjakan pekerjaan yang spesifik tersebut.

Spesialisasi pekerjaan dilakukan dalam rangka mengurangi kompleksitas dan permasalahan manajerial dalam organisasi. Hal ini sesuai dengan pernyataan Gibson, Ivancevich dan Donnely, yang mengungkapkan bahwa: hal yang penting dalam mengembangkan struktur organisasi adalah penentuan berapa banyak pembagian kerja berdasarkan kemampuan dan keahlian karyawan.

Tujuh, mengenai pelaksanaan tugas dan kewajiban yang sesuai dengan pedoman kerja. Sebagian besar $(62,5 \%)$ tenaga kependidikan melaksanakan tugas dan kewajiban dengan baik sesuai dengan pedoman kerja. Pedoman kerja yang melandasi pekerjaan setiap pekerja merupakan hal yang penting, karena pedoman kerja merupakan patokan dasar yang dapat dijadikan pegangan oleh pekerja dalam melaksanakan tugas dan kewajibannya, sehingga pekerjaan mereka dapat dikerjakan dengan baik.

Untuk itu dalam proses pembuatan pedoman kerja, sebaiknya mengacu pada prosedur; (a) Penyelia bekerjasama dengan bawahan dalam menyusun pedoman kerja, (b) Setiap pekerja menyusun pedoman tentatif bagi setiap aspek pekerjaannya, dan (c) Pedoman kerja digunakan oleh setiap pekerja untuk dijadikan bahan pertimbangan dalam penilaian kerja baik secara kolektif maupun individu. (Simamora, 1997: 150).

Delapan, mengenai pengetahuan dan pendidikan yang dimiliki tenaga kependidikan sudah memenuhi kualifikasi pekerjaan. Sebagian $(43,75 \%)$ tenaga kependidikan memiliki pengetahuan dan pendidikan yang memenuhi kualifikasi pekerjaan.

Tingkat pendidikan seorang pekerja, cenderung berkaitan dengan tingkat pengetahuan dan pemahaman pekerja terhadap pekerjaannya. Tingkat pendidikan juga diharapkan dapat menunjang kualitas hasil kerja yang dilakukan pekerja dalam melaksanakan pekerjaannya, sehingga seharusnya semakin tinggi tingkat pendidikan semakin tinggi pula kualitas hasil kerjanya.

Tingginya kualitas kerja dapat dijadikan modal bagi pekerja untuk memperoleh jabatan 
dan pendapatan yang lebih tinggi. Hal ini merujuk pada pendapat bahwa: pendidikan yang berhasil diselesaikan seseorang biasanya menentukan pendapatan, kelas sosial serta tingkat intelektualitas dari orang yang bersangkutan (Kasali, 1999: 87).

Sembilan, mengenai kemampuan dan keterampilan yang dimiliki oleh tenaga kependidikan yang telah sesuai dengan pekerjaan yang diembannya. Sebagian $(43,75 \%)$ tenaga kependidikan memiliki kemampuan dan keterampilan yang sesuai dengan pekerjaan saat ini. Setiap pekerja memiliki pengalaman kerja di bidang yang berbeda-beda, semakin lama pekerja tersebut bekerja di bidang yang sama maka kemampuan dan keterampilannya dalam melaksanakan tugas-tugas rutin di bidang tersebut akan meningkat seiring waktu. Sesungguhnya berdasarkan deskripsi tugas, spesifikasi tugas dapat dikembangkan berdasarkan syarat minimum, yaitu Pendidikan dan pengalaman, Sikap mental dan kejiwaan, Kondisi jasmani, Kemampuan teknis dan keterampilan berdasarkan pelatihan, dan Tanggung jawab individu dan organisasi (Komaruddin, 1993: 119).

Sepuluh, mengenai kesesuaian jam kerja dengan beban kerja tenaga kependidikan. Sebagian $(46,875 \%)$ tenaga kependidikan menjalani beban kerja yang sesuai dengan jam kerja. Hari kerja menunjukkan jumlah hari yang tersedia untuk bekerja bagi karyawan. Waktu kerja adalah satuan waktu tertentu yang tersedia untuk bekerja, misal dalam jam per tahun atau menit per tahun. Hari kerja dan waktu kerja merupakan hal yang penting untuk diketahui dalam melakukan analisis beban kerja. Berdasarkan hari kerja dan waktu kerja, dapat diketahui bagaimana gambaran penggunaan waktu yang tersedia untuk bekerja oleh karyawan.

Berdasarkan hasil observasi tenaga kependidikan Fakultas Y Universitas X bekerja lima hari dalam seminggu dari hari Senin hingga Jumat atau sebanyak 261 hari kerja dalam setahun. Adapun jam kerja karyawan per hari yaitu sejak pukul 08.00 sampai dengan pukul 16.00.

Jenis-jenis kegiatan tidak produktif yang berhasil diamati dan hampir didapati di seluruh unit tata usaha yaitu mengobrol sesama karyawan, membaca koran atau majalah, menggunakan sambungan internet untuk hal-hal yang tidak perlu, terlambat datang kerja, dan pulang kerja lebih awal. Adapun kegiatan pribadi yang dilakukan oleh karyawan untuk menghilangkan penat atau kelelahan, yang berhasil diamati meliputi kegiatan makan, minum, shalat, tidur, mendengarkan musik dan olahraga ringan.

Sebelas, mengenai pelaksanaan tugas dan pekerjaan sesuai dengan pedoman yang diberikan. Sebagian besar $(62,5 \%)$ tenaga kependidikan melaksanakan tugas dan pekerjaan dengan baik sesuai pedoman kerja yang diberikan. Pedoman kerja diberikan kepada setiap tenaga kependidikan agar mereka mengetahui apaapa saja yang menjadi tugas pokok dan fungsi nya masing-masing sehingga diharapkan setiap tenaga kependidikan mampu melakukan tugasnya dengan baik.

Mangkuprawira (2003) menyatakan jika karyawan bekerja di bawah standar, dapat diartikan bahwa estimasi standar yang ditetapkan lebih tinggi dibanding kapasitas karyawan itu sendiri sehingga beban kerja yang diemban terasa berlebih. Pedoman kerja inilah yang menjadi dasar dalam penghitungan beban kerja.

Dua belas, mengenai atasan yang puas ter hadap tugas yang diselesaikan. Sebagian $(43,75$ $\%)$ tenaga kependidikan menyelesaikan tugas yang membuat atasan puas. Atasan akan merasa puas kepada bawahannya jika bawahannya dapat memenuhi target pencapaian yang telah ditetapkan. Hal ini berlaku juga bagi penilaian pencapaian target tenaga kependidikan.

Tiga belas, mengenai kesesuaian beban kerja sehari-hari dengan kemampuan tenaga kependidikan. Sebagian (50\%) tenaga kependidikan memiliki kemampuan yang sesuai dengan beban kerja sehari-hari. Yang perlu diperhatikan berkaitan dengan pelaksanaan beban kerja di setiap unit kerja adalah kapasitas atau kompetensi pegawai yang melaksanakan tugas. Oleh karenanya peningkatan kompetensi pegawai merupakan faktor fundamental yang harus diperhatikan.

Empat belas, mengenai perusahaan telah mengevaluasi kesesuaian beban kerja yang diberikan dengan jumlah karyawan yang ada. Sebagian $(34,375 \%)$ tenaga kependidikan merasa bahwa perusahaan telah mengevaluasi kesesuaian beban kerja yang diberikan dengan jumlah karyawan yang ada. Kekurangan jumlah karyawan administrasi akademik dan kemahasiswaan mengindikasikan bahwa dibutuhkan karyawan dengan kapasitas yang lebih tinggi untuk mengerjakan beban kerja yang ada seh- 
ingga dapat dikerjakan oleh satu orang. Hal ini untuk menghindari institusi menggaji karyawan lebih banyak dari yang seharusnya atau dengan kata lain untuk menghindari inefisiensi biaya.

Lima belas, mengenai kemampuan tenaga kependidikan beradaptasi terhadap perubahan dan selalu terbuka untuk ide-ide baru. Sebagian besar $(56,25 \%)$ tenaga kependidikan mampu beradaptasi terhadap perubahan dan selalu terbuka untuk ide-ide baru. Seringkali perubahan pimpinan akan menimbulkan perubahan kebijakan yang pada akhirnya juga akan mengubah tata kerja dan alur kerja organisasi. Oleh karena setiap pegawai seharusnya memiliki sikap adaptasi yang fleksibel dan selalu terbuka untuk ide-ide baru.

Dari pengamatan di lapangan, tenaga kependidikan Fakultas Y Universitas X sedikit khawatir terhadap adanya perubahan kebijakan, namun jikalau ada perubahan mereka tidak dapat menolaknya dan hanya bisa menjalankannya. Semakin minimnya perubahan akan semakin disukai, karena dengan begitu mereka tidak perlu melakukan perubahan pada pola pekerjaan yang telah mereka jalani sehari-hari.

Enam belas, mengenai perusahaan telah melakukan evaluasi pekerjaan di setiap unit kerja. Sebagian $(37,5 \%)$ tenaga kependidikan berpendapat bahwa perusahaan belum melakukan evaluasi pekerjaan di setiap unit. Pada saat peneliti memberikan kuesioner kepada setiap tenaga kependidikan, tidak sedikit dari mereka yang bertanya apakah penelitian ini hanya bersifat penugasan sekadarnya saja atau memang merupakan evaluasi atas pekerjaan yang mereka lakukan. Harapan atas adanya evaluasi kerja ternyata sangat tinggi, hal ini dikarenakan para tenaga kependidikan mengharapkan adanya penilaian yang jujur dan adil atas pekerjaannya, sekaligus sebagai wadah tempat menampung aspirasi dan keluh kesah mereka.

Tujuh belas, mengenai kemampuan mengenali masalah dan mencari solusi terbaik. Sebagian besar $(53,125 \%)$ tenaga kependidikan mampu mengenali masalah dan mencari solusi terbaik. Lamanya pengalaman kerja pada suatu bidang tertentu akan menjadikan seorang pekerja menjadi ahli pada bidangnya. Hal ini pula yang tampak dari sebagian besar tenaga kependidikan Fakultas Y Universitas X, mereka dapat mengenali masalah yang sering terjadi berulang kali sehingga mereka dapat memberikan solusi yang tepat.

Jika setiap tenaga kependidikan memiliki kemampuan tersebut maka pelayanan akademik dan kemahasiswaan kepada mahasiswa akan semakin baik dan waktu pelayanan pun semakin efisien.

Delapan belas, mengenai ketelitian dalam menjaga kualitas hasil pekerjaan. Sebagian $(46,875 \%)$ tenaga kependidikan memiliki ketelitian dalam menjaga kualitas hasil pekerjaan. Dengan adanya beban kerja yang banyak dan beragam mengakibatkan tenaga kependidikan Fakultas Y Universitas X kurang berhati-hati dan teliti atas kualitas hasil kerjanya. Hal ini mereka sadari sendiri mulai dari hal yang kecil seperti salah ejaan saat menulis surat hingga mencetak lembar ijazah dengan setting yang salah.

Contoh tersebut seharusnya dapat dihindari sehingga tidak terjadi pemborosan waktu kerja dan pemborosan biaya operasional fakultas. Oleh karena itu, perlu dilakukannya pengecekan atau pemeriksaan pekerjaan sebelum mereka cetak atau tampilkan kepada pihak yang memerlukannya.

Terakhir, mengenai kemampuan membuat keputusan yang tepat dalam bekerja. Sebagian besar $(53,125 \%)$ tenaga kependidikan mampu membuat keputusan yang tepat dalam bekerja. Sejalan dengan lamanya pengalaman kerja sebagian besar tenaga kependidikan Fakultas Y Universitas $\mathrm{X}$ memberikan bekal bagi diri pribadi mereka untuk dapat membuat keputusan yang tepat dalam bekerja.

Sebagian besar dari tenaga kependidikan telah bekerja di unit kerja yang sama selama 5 10 tahun. Mereka sudah dapat memperkirakan permasalahan apa yang mungkin dapat terjadi dalam situasi yang berbeda-berbeda.

Demikian hasil penelitian dan pembahasan yang telah dilakukan peneliti selama kajian analisis beban kerja tenaga kependidikan Fakultas Y Universitas X.

\section{SIMPULAN}

Dari hasil penelitian analisis beban kerja tenaga kependidikan di Fakultas Y Universitas $\mathrm{X}$ dapat disimpulkan bahwa beban kerja berdasarkan faktor analisis pekerjaan dapat dilakukan dengan baik apabila terdapat kejelasan pedoman atau petunjuk kerja, adanya 
pemahaman yang baik tentang pedoman kerja masing-masing individu, adanya kejelasan tugas dan tanggung jawab pekerjaan, kesesuaian antara pedoman kerja dengan pengetahuan, kemampuan, dan keahlian yang dimiliki setiap tenaga kependidikan, adanya bimbingan dari atasan, kesesuaian dengan tugas dan tanggung jawab yang diberikan dengan kemampuan setiap tenaga kependidikan, dukungan kemampuan dan keterampilan yang dimiliki tenaga kependidikan yang sesuai dengan pekerjaannya, dan latar belakang pengetahuan dan pendidikan yang memenuhi kualifikasi pekerjaan.

Beban kerja berdasarkan faktor kinerja tenaga kependidikan dapat dilakukan dengan baik apabila adanya kesesuaian waktu kerja dengan beban kerja, pelaksanaan tugas dan pekerjaan sesuai dengan pedoman kerja, adanya dukungan dari atasan yang merasa puas terhadap tugas bawahan, beban kerja sesuai dengan kemampuan masing-masing pegawai, adanya evaluasi beban kerja terhadap jumlah pegawai yang ada secara berkala, kemampuan adaptasi terhadap perubahan dan selalu terbuka terhadap ide-ide baru, adanya kesungguhan pelaksanaan evaluasi pekerjaan di setiap unit kerja, kemampuan pengenalan masalah dan mencari solusi terbaik, adanya ketelitian dalam menjaga kualitas pekerjaan, dan kemampuan pengambilan keputusan dalam bekerja.

Berikut adalah saran yang berkaitan dengan hasil penelitian, diantaranya perlu adanya evaluasi beban kerja secara berkala di setiap unit kerja yang terdapat di Fakultas Y Universitas $\mathrm{X}$ dan seharusnya setiap pegawai di Fakultas $\mathrm{Y}$ Universitas $\mathrm{X}$ dapat memberikan penilaian secara jujur dan terbuka atas tugas dan tanggung jawab yang diembannya.

\section{DAFTAR PUSTAKA}

Badan Kepegawaian Negara. (2011). Pedoman penataan pegawai negeri sipil. Jakarta: BKN.

Dessler, G. (2004). Manajemen sumber daya manusia. Jakarta: Indeks.

Hasan, M. I. (2002). Pokok-pokok materi metodologi penelitian dan aplikasinya. Jakarta: Ghalia Indonesia.

MENPAN. (2004). Keputusan menteri pendayagunaan aparatur negara nomor: kep $/ 75 / \mathrm{m}$. pan/7/2004 tentang pedoman perhitungan kebutuhan pegawai berdasarkan beban kerja dalam rangka penyusunan formasi pegawai negeri sipil. Indonesia.

Mangkuprawira, S. (2003). Manajemen sumber daya manusia strategik. Jakarta: Ghalia Indonesia.

Moekijat. (2008). Analisis jabatan. Bandung: Mandar Maju.

Nasution, S. (2003). Metode research (penelitian ilmiah). Jakarta: Bumi Aksara.

Rivai, H. V. (2006). Manajemen sumber daya manusia untuk perusahaan, dari teori ke praktik. Jakarta: Rajagrafindo Persada.

Siagian, S. P. (2008). Manajemen sumber daya manusia. Jakarta: Bumi Aksara. 